\title{
Rural village Gnjili Potok - road sign towards happiness and freedom (Some geographical aspects of sustainable development)
}

\author{
Goran Rajović $^{1, a}$, Jelisavka Bulatović ${ }^{2, b}$ \\ ${ }^{1}$ Street Vojvode Stepe 252, Belgrade, Serbia \\ Phone: 0038161/19-24-850 \\ ${ }^{2}$ Department of Technology and Management, College of Textile Design, \\ Street Starine Novaka 24, Belgrade, Serbia \\ Phone: 003861/ 30-82-651 \\ ${ }^{a, b}$ E-mail address: dkgoran.rajovic@gmail.com , jelisavka.bulatovic@gmail.com
}

Just look deep into, deep to nature, and then all you will better understand

Albert Einstein

\begin{abstract}
The role of the village must to be first class, because are their potentials major development power future of Montenegro. This requires radically new attitude of society and science to the village. It must they are develop a new concept, a comprehensive rural development, which will be based on demographic, natural, economic and socio-cultural resources. Responsible role in the development of this concept has both geographical science, it's the comprehensive approach should combine research efforts and results of other sciences. Rural village Gnjili Potok provides outstanding opportunities to create new forms of co-existence in response to the disintegration of family, cultural and social structures in terms dictated by the post-modern global world.
\end{abstract}

Keywords: Village; sustainable development

\section{INTRODUCTION}

Eco-villages are assembled into a global network of eco-villages (GEN) whereby achieve mutual cooperation and exchange of experiences. The first project an eco-village in the world was realized in 1995, bringing together only nine settlements. Today, after nineteen years of these ideas and practices, in the world there are more than 15.000 settlements in which are lives of people takes place according to the principles of sustainable development $[1]$. 
The aim of the project GEN is that the economic activities the potential eco-village be directed towards the moderate use of natural resources and stimulate alternative means of securing income. In that way are supports the preservation and protection of nature and on the other side's promotes the economic and social condition of the population [2-3]. United in a common attitude and understanding of environmental, socio-economic, cultural and spiritual values, members of the Eco-villages are usually people who have chosen an alternative to large centralized electric, water and wastewater systems [4].

Perhaps the best illustration of what the real eco-village means can offer the oldest Danish eco village "Økosamfundet Dyssekilde", which is also author him of these lines, had the opportunity to visit. Namely, in this eco-village is located 74 uniquely are designed houses and apartments that are completely energy independent, seven windmill to generate electricity, a huge plant for recycling, beautiful gardens, fascinating green spaces ... The knowledge and experience gained room in this beautiful spot leave an indelible mark on my world, attitudes and aspirations in life. Cams I saw and felt how things work, how is the community of 118 people in "Økosamfundet Dyssekilde" consecrated and deeply committed to the mission of preserving the Earth.

In accordance with this example in practical problem solving for sustainable rural development in Montenegro, the competent state authorities should be more than ever, that take into account the proposals of relevant scientific institutions and for this purpose would have had to make their reorganization and modernization, which implies their financial and human resources consolidation and technical equipment [5]. Rural settlement Gnjili Potok provides excellent opportunities to create new forms of coexistence in response to the disintegration of family, cultural and social structures in terms dictated by the post-modern global world.

\section{RESEARCH METHODOLOGY}

The methodological approach applied in this work is multidisciplinary. The research results of different scientific fields are adapted to needs of the work [6-7]. We used methods of research, assessment methods and quality [8-10].

These methods are extremely important for the planning of environmental quality, the decoration and protection of the area, as well as for improving environmental quality and of life of residents [11]. In the Hilly and Mountainous regions of Montenegro, in methodological terms, the analysis gives on settlement level in accordance with the criteria those applied Common Agrarian Policy.

By using methods of analysis and synthesis based on the individual elements of the space is obtained a complex whole"[12-13]. In addition to the above mentioned general methods modeled on research Pavlovic and Jovanovic [11].

(2009) were used and the specific methods: methods of direct research, geographic and ecological research method and the method of direct observation space and of components [14-15].

\section{ANALYSIS AND DISCUSSION}

Gnjili Potok occupies a total area of $8.83 \mathrm{~km}^{2}$ covering an area of $8,83 \mathrm{~km}^{2}$. It is surrounded by two rural settlements: Bare Kraljske and Kralje. Gnjili Potok away from of 8 $\mathrm{km}$ Andrijevica, Mateševa $15 \mathrm{~km}$, Berana $23 \mathrm{~km}$ and Kolašina $28 \mathrm{~km}$. To rural settlement 
Gnjili Potok is coming from two directions. Most often it comes from the Andrijevice, through rural villages Kralje or from the direction of Kolašina (roads prime importance), through rural villages Bare Kraljske [16-17]. Until the rural settlement Gnjili Potok is also possible to reach vehicular traffic from rural settlement of the Vranještica, through Backkog Brda and Lisa, that is, from bare foothills of Komova, through Štavne. Both roads are joined at the saddle Trešnjevik. Transport and communications of settlement roads increased from the hamlet Ĉuka, through the Lomova to the foot Trešnjevik, as the road from the hamlet Miravĉine [18-19].

Rural village Gnjili Potok provides outstanding opportunities to create new forms of co-existence in response to the disintegration of family, cultural and social structures in terms dictated by the post-modern global world [20]. Valuable natural and cultural heritage that is and in addition to all adversity preserved in modern conditions may represent a huge potential for development if its concept is based on respect for the principle of sustainability. Planning and implementation of this type of rural development is very complex and demanding, especially in terms of the enormous heterogeneity of the small physical space, as well as the economic backwardness of rural areas and the country as a whole. Sustainable rural development essentially depends on the practical application of a combination of the concept of multifunctional agriculture and other economic development activities in line with the available natural and human resources, the overall improvement of living conditions and socio-economic status of villages and rural communities [21].

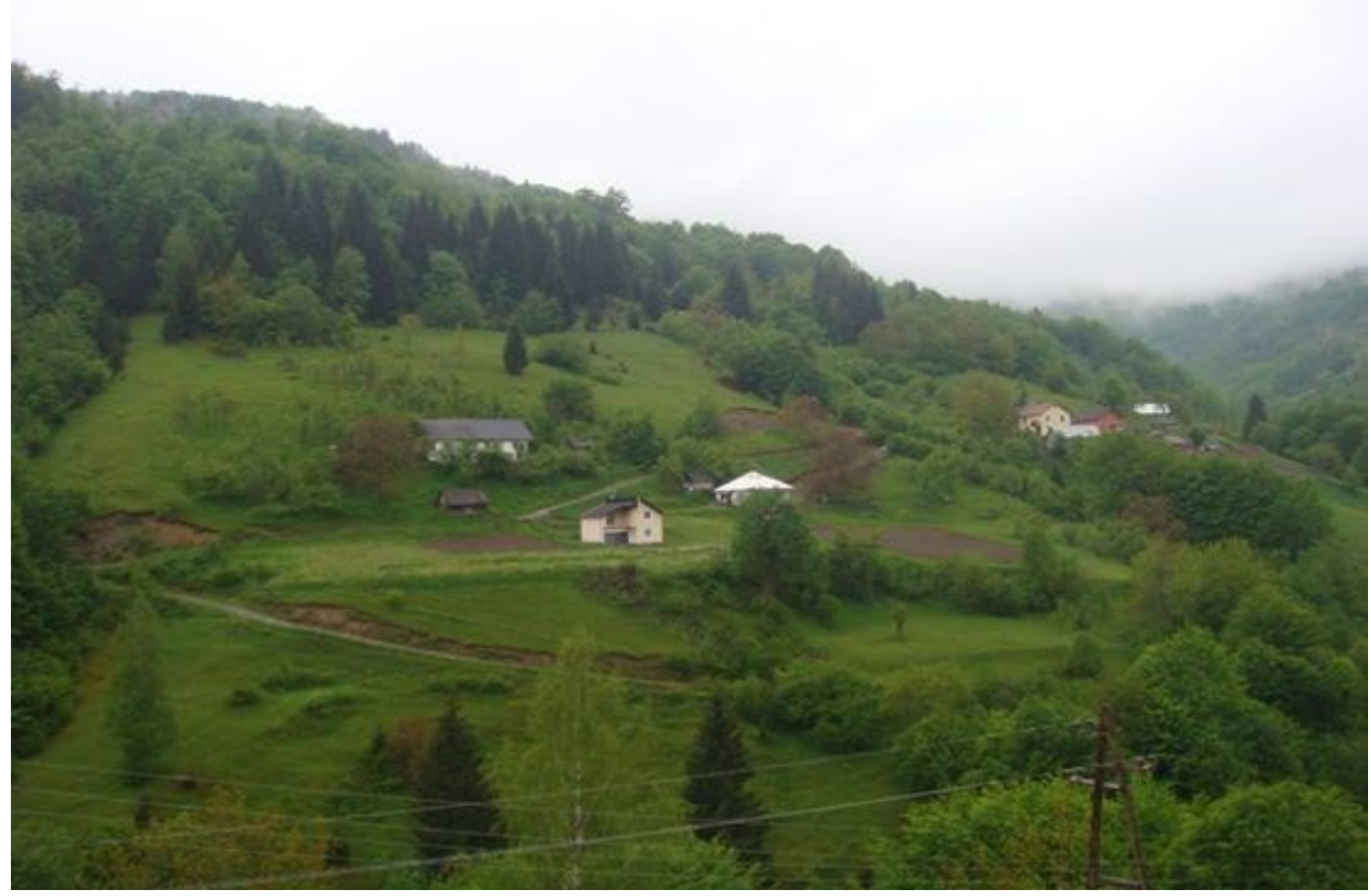

Figure 1. A fascinating look northwestern part of the Gnjilog Potok- residential buildings framed by deciduous and coniferous forests. 
With the intention of maintaining the integrity of the original vision among its members, GEN is a network organization, has developed the concept of sustainable audit function, which is the measuring tool for eco-villages and co-housing community. According to Dawson [22], Carrillo-Hermosilla et al [23], Cheng and Hu [24], Barton [25], the method is called a "quick assessment of sustainability community" and consists of simple checklists: Ecological sustainability-a sense of place, food availability, production and distribution, infrastructure, construction and environmental transport, recycling, care for water, waste water management, integrated renewable energy systems, the establishment of ecological principles. Then follows sustainable are education, cultural sustainability, economic sustainability, political sustainability and sustainable communications, and spiritualism sustainable, sustainable health. Natural Steps are creative and novel approach to address the challenges related to the environment based on consensus and systems thinking. Their purpose is to develop and share a common framework, which consists of understanding the scientific principles that can serve as a compass and guide society towards a sustainable future through: decrease mining and use of fossil fuels, eliminating the use of hazardous product generated in society, protection of biodiversity and ecosystems, efficient use of resources To save money, reduce waste related to human needs.

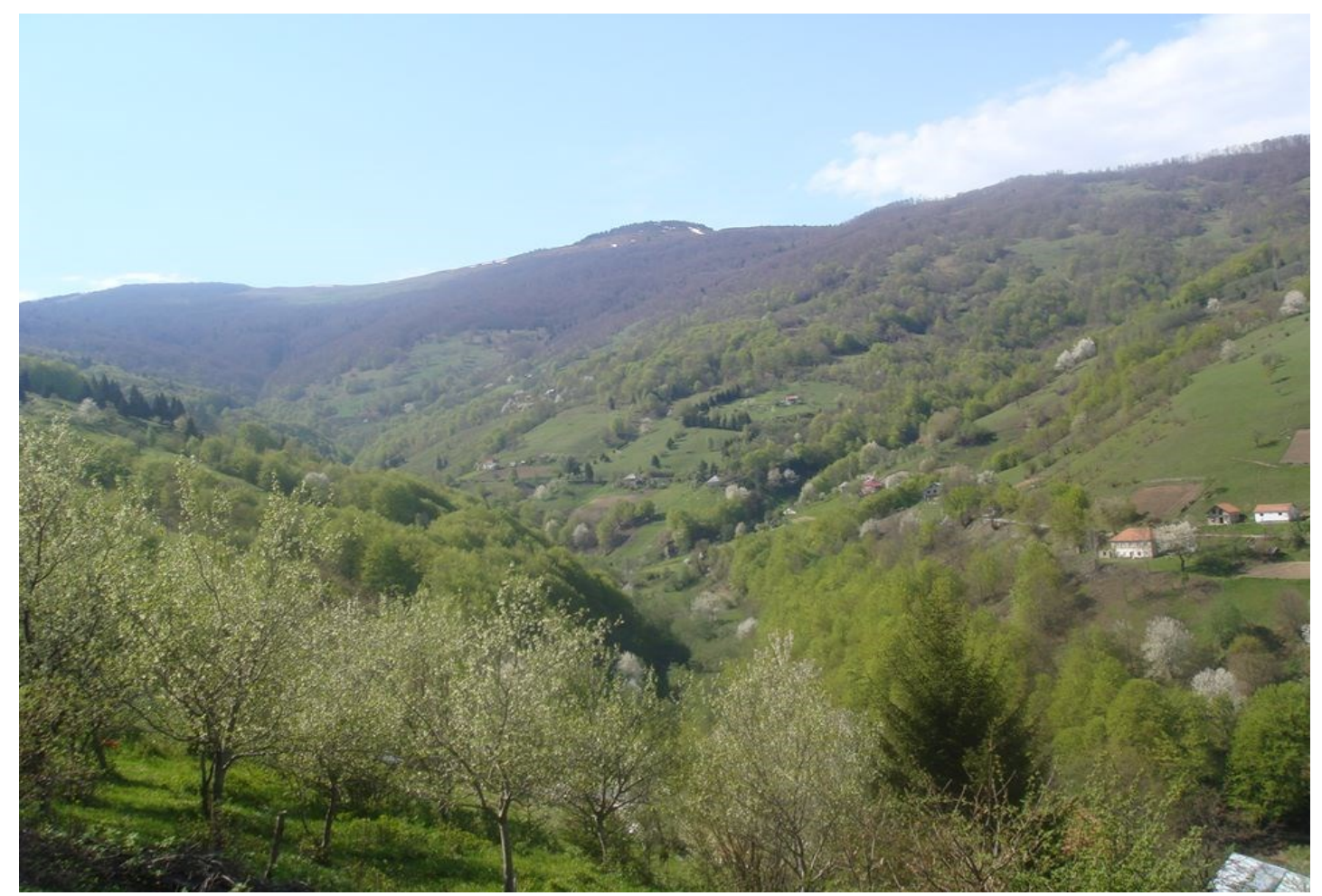

Figure 2. Landscapes which is breathtaking - the northern part of the rural village Gnjili Potok the extends to the foot of the mountain Lise.

Sustainable rural development is necessarily local and is only possible if it is to gain favorable (necessary and sufficient) not only global but also local conditions. Therefore it is necessary to launch a legislative initiative to revive the local village government and institutional extension of the jurisdiction of rural communities as a trusted form of direct local government in the Montenegrin folk tradition. To the same end, useful to also in Hilly and Mountainous and border areas of Montenegro initiated the formation of small rural 
municipalities and allow their demographic and social sustainability [5]. Considering on current state where there is a rural village Gnjili Potok strategic utilization of the economic potential of the village to Panić and Živanović [26], would imply: utilization of excess housing, employment available human resources and attracting new workers returning young people on the village, sales of own agricultural and other products to a higher stage of processing, without the cost of transportation, rental of retail space, consumption of time and energy, by favorable prices creating better living conditions for young people to stay in rural areas through rural development and raising the living standards on desired higher level, formation of a new family business, with better use of existing resources and their development needs new direction, developing new and better utilization of the existing capacity of members of households.

Some of the ideas and tips on how to develop a rural village, portal Magazin [27], considered one most important, and that might be applicable and studied on geo-space Gnjili Potok:

1. Organization of the festival - typical for rural areas fruit festival, festival of brandy, winter stores, singing, national costumes folklore the game and songs ... Manifestations are a phenomenon which increasingly gaining importance in industry events. Organized events may be drivers of rural tourism development because they are an increasingly important factor when making decisions about travel. These results from the affinity of modern tourists who want to visit the new rural destinations through manifestations acquainted insufficiently known culture, have fun and gain new experiences. One of the main features manifestations is to remain remembered as a unique experience for all their visitors.

2. Making home and home souvenirs. According to Ivkov-Dzugarski et al [28], souvenirs

represent items that carry a special label destinations where they come from, and are made to serve tourists in memory of the place where have experienced a stay. Authenticity and easy recognition of the main features of most souvenirs. Souvenirs and transmit broader picture of the village of which they are incurred.

3. Pedestrian paths - paths of health, romantic paths, historic trails, forest trails, meadow trail ... Laws [29], points out that "the no tourist attractions would not be tourism, but without tourism would not be neither tourist attractions". Walking tours tourists provide enjoyment of nature, emotional release, and are excellent for gaining fitness. They can be combined with other activities - exploring caves, climbing ... Wall and Mathieson [30], focus the importance of spatial configuration as an important attribute of tourist attractions. Accessibility attractions also include the issue of roads, paths and entrances, which are required to visit certain sites and buildings [31-32].

4. The famous coffee bar- cafe bar for centuries enjoyed a high status and therefore it is not surprising that it was one of the most important social institutions. It is, important to remember whenever we stepped into her, a temple of modern European civilization! Local cafe "Krčma" in Trešnjevik becomes vivid place, in which during the evening now drop by and tourists, which attracts people from the neighboring villages. Private store in village records increasing traffic.

5. The Memorial house or a house of traditional crafts, of family photographs, folk costumes, tools ... A new age, in which in recent years in many countries, offering more opportunities for the restoration of traditional craft skills through creative economy and development of market of tourist services, not particularly influenced the revitalization of traditional crafts in Montenegro. Refurbishment of old crafts, besides attractiveness of the market, there are other express value, and that the 
protection of endangered of intangible and tangible cultural heritage in the area of skills related to traditional crafts. Intangible cultural heritage signifies, among other things, practices, knowledge and skills related to traditional handicrafts, in which communities, groups and individuals recognize as part of their cultural heritage [33]. "It is transmitted from generation to generation, and depending on the environment, interactions with nature and history, provides a sense of identity and of continuity and thus promotes respect towards cultural diversity and creativity" [34]. Sustainable development of traditional crafts could be moving in two directions, production of a replica of craft products and souvenir production (and miniatures), as well as the application of traditional techniques and modern ornaments utilitarian or decorative objects.

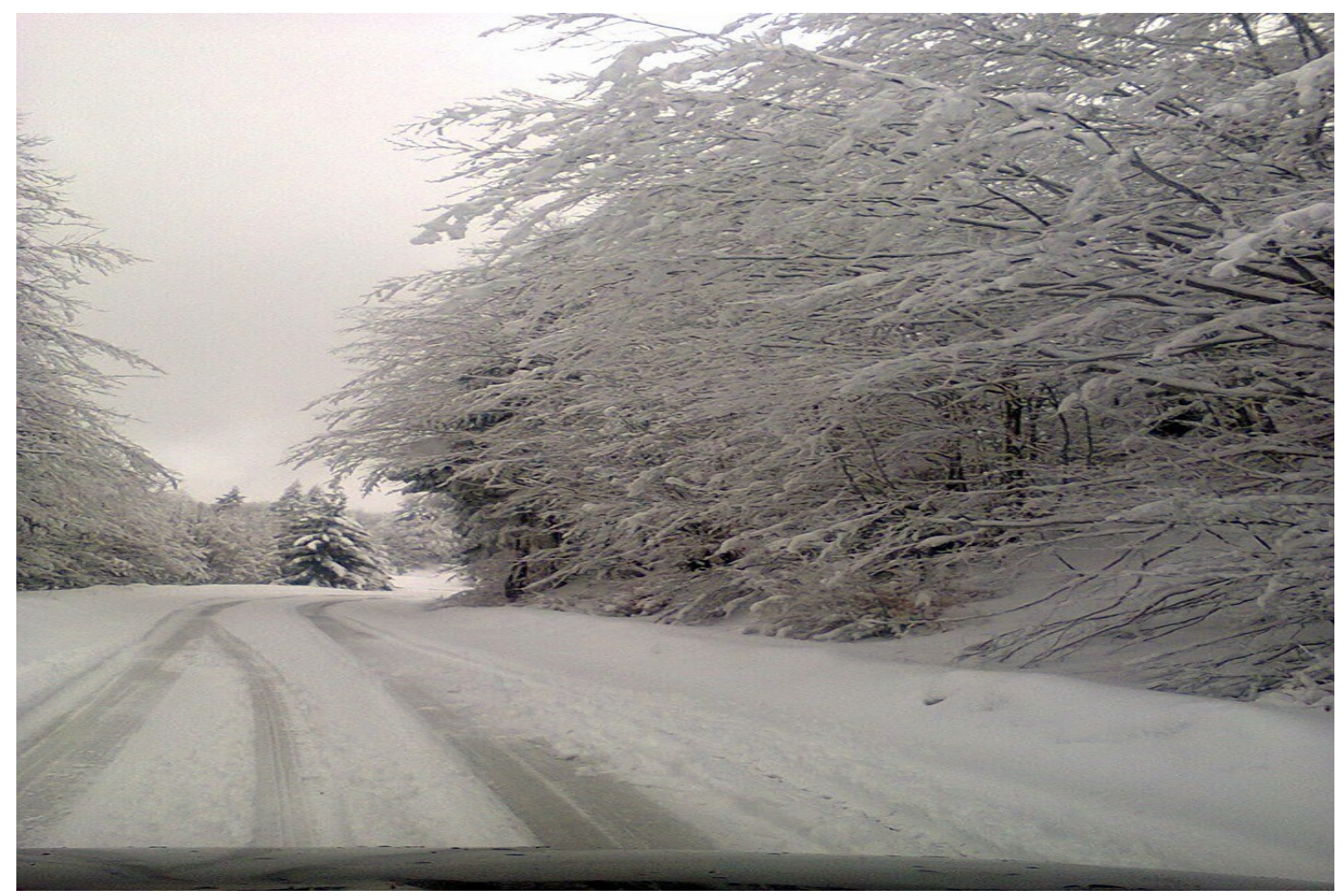

Figure 3. Winter Idyll - roads across Trešnjevik.

6. Gastronomic Event - A Competition in preparing meals, food grade ... Food is a big mover and generator of tourism arrivals. Cult food has always existed in this region, a delicious traditional delicacies cannot resist nor many foreigners in and cafe "Lekić" in Trešnjevik. The pleasure becomes greater even larger if the gastronomic event may incorporate with some hunting and fishing [35].

7. Rural tourism and they accommodations. All this should be part of a general offer of the village and the villagers helping each other, that all the tourist action going through the local commune Kralje or the Tourist Organization municipalities of Andrijevica. It is necessary in one place unite the overall offer of the village and within one accommodation offer and a series of related content. For now, in close 
proximity a settlement, in ridge Trešnjevik is located catering establishment "EkoDom" with beds on the upper floor and two bungalows [36-37].

8. Events in the village - some highlight for tourists. For example, a small zoo of domestic animals, going to summer pastures and shepherds to be seen herding sheep, show hunting, local papers ...

9. Cleanliness and hygiene in the village - the key thing for tourism. Village which is taken care of, clean and tidy, in which has flowers, walking paths, bench seating and beautiful nature, with friendly people and tourist attractions will always attract tourists.

10. Cooperative - joining in village cooperative. In order to agricultural holdings have survived on market, they must organize themselves into a cooperative. According Nedeljković [38], everyone farming household is too small as a production entity that could be an equal partner in the market. It cannot achieve the needed quality, quantity and continuity of agricultural products, cannot be conveniently to procure intermediate goods, processing and sale of finished products. If the cooperative has a larger the number of members it is competitive. The cooperative is a way of business and the need for the survival of small producers. The cooperative as a form of association that offers maximum stability and safety of agricultural producers. In the countries of the European Union cooperative movement is organizational and entrepreneurial system, without which cannot imagine functioning and development of agriculture. These are just some of the indicators which point to the importance of co-operatives and the cooperative movement in the developed economic countries which and we should aspire.

\section{CONCLUSIONS}

The role of the village must to be first class, because are their potentials major development power future of Montenegro. This requires radically new attitude of society and science to the village. It must they are develop a new concept, a comprehensive rural development, which will be based on demographic, natural, economic and socio-cultural resources. Responsible role in the development of this concept has both geographical science, it's the comprehensive approach should combine research efforts and results of other sciences [39].

Our research evidence based in similar studies Radovanović [40] emphasizes that it is necessary to take into account the specificities of rural settlements Gnjili Potok and its Course there are also numerous other reasons and causes. Čavrak [41], points out that one of the most is often represented erroneous conceptual and strategic approach to the development of rural areas, which is reflected in the fact that in traditional rural areas implement completely "the new" so-called "modern" strategies that are generally not take into account the two traditional advantages that have rural areas, what kinds after all and a village Gnjili Potok. Order to young people been interested live in them and they work.

There are, first of all: the development of infrastructure (especially roads), stimulating credit conditions, technical assistance (intellectual services especially in the manufacturing section), continuous education in order to acquire special knowledge about rural economy, access to market and technological information, technological and organizational development services and marketing orientation in primary agriculture, greater attention neglected general social issues (assistance in family planning, improved medical services, development of settlements ... [40]. 
However, should emphasize and great effort of the Government of Montenegro to a wide range of different support programs generate entrepreneurial activity in rural areas. Why then are the results of these efforts yet relatively modest? According to Čavrak [41], is certainly the many reasons: lack of appropriate strategies and programs, a relatively modest amount of funds which are financing projects, a lack of understanding of local authority roles and tasks in to encourage and support local social development and the lack of adequate institutional support this and such development.

\section{References}

[1] Eco-village info Gazette of Montenegro - Development of cultural information center, Countdown to 2010: the development of a network of eco-villages in Bosnia and Herzegovina, Serbia and Montenegro, Available from: http://www.nvomost.files.wordpress.com (25.06 2014).

[2] Joseph L., Bates A., Communities Magazine 117(1-4) (2003).

[3] Winston N., Advances in Ecopolitics 9 (2012) 85-103.

[4] Corm Alternative Exchange Association, Eco-village, Available from: http://www.cromalternativemoney.org (26.06 2014).

[5] Village in Serbia, Available from: http://www.vreme.co.rs (27.06 2014).

[6] Daniela Gîfu, Mirela Teodorescu, International Letters of Social and Humanistic Sciences 18 (2014) 48-57.

[7] Sorin Mihai Radu, Nicolae Iliaş, Eduard Mija, International Letters of Social and Humanistic Sciences 18 (2014) 58-69.

[8] Stefan Vlăduţescu, International Letters of Social and Humanistic Sciences 18 (2014) 80-89.

[9] Stefan Vlăduţescu, International Letters of Social and Humanistic Sciences 20 (2014) $37-45$.

[10] Stefan Vlăduţescu, International Letters of Social and Humanistic Sciences 22 (2014) 41-49.

[11] Pavlović B., Jovanović B., Zbornik radova Географски факултет Универзитета у Београду, LVII (2009) 165-180.

[12] Ioan Constantin Dima, Mirela Teodorescu, Daniela Gîfu, International Letters of Social and Humanistic Sciences 20 (2014) 46-55.

[13] Ioan Constantin Dima, Daniela Gîfu, International Letters of Social and Humanistic Sciences 22(2014) 77-84.

[14] Rajović G., Bulatović J., Ecologica 15(51) (2009) 45-52.

[15] Rajović G., Bulatović J., Zaštita prirode 61(2) (2011) 111-128.

[16] Rajović G., Istraživanje i razvoj 15(32-33) (2009) 75-77. 
[17] Rajović G., Bulatović J., Journal of Social Economics Research 1(3) (2014)20-39

[18] Rajović G.,Rajović D., Natural and socio economic characteristics of rural settlements Gnjili Potok, "The Agency PC system", Belgrade, 2010.

[19] Rajović G., Bulatović, J., Tactful Management Research Journal 2(6) (2014) 1-11.

[20] Rajović G., Bulatović, J., Vestnik OrelGAU 1(46) (2014) 3-13.

[21] Bogojević M., Sustainable Rural Development, Available from: http://www.zdravasrbija.com (28.06 2014).

[22] Dawson, Jonathan, Ecovillages - New frontier for Sustainability, Green Books Ltd, 2006.

[23] Carrillo-Hermosilla J., Del Río González P., Konnola, T., Eco-innovation. UK: Palgrave Macmillan, 2009.

[24] Cheng H., Hu Y., Journal of Environmental Monitoring 12(1) (2010) 119-126.

[25] Barton H., Sustainable communities: the potential for eco-neighborhoods, Routledge, 2013.

[26] Živanović J., Panić M., Specifics villages in Serbia in the Context of tourism potential, Available from: http://www.selo.co.rs (29.06 2014).

[27] Magazin - National portal, How to Develop a Serbian village - ideas and advice for the development of villages and rural tourism, Available from: http://www.magacin.org (30.06 2014).

[28] Ivkov-Dzugarski A., Kovačević T., Zakić L., Bulletin of the Serbian geographical society LXXXVIII(4) (2008) 59-69.

[29] Laws E., Tourist Destination Management, London: Routledge, 1995.

[30] Wall G., Mathieson A., Tourism: Change, Impacts and Opportunities, London: Prentice Hall, 2006.

[31] Page S., Dowling R., Ecotourism. London: Prentice Hall, 2002.

[32] Wall G., Mathieson A., Tourism: Change, Impacts and Opportunities, London: Prentice Hall, 2006.

[33] Republic of Serbia, Ministry of Tourism, Trade and Communications (2014), about the old crafts in Serbia, Available from: http://www.starizanati.gov.rs (01.07 2014).

[34] Rajović G., International Journal of Migration and Residential Mobility 1(1) (2014) 28-49.

[35] Rajović G., Bulatović J., Applied Journal of Hygiene 2(3) (2013) 15-24.

[36] Rajović G., Bulatović J., Anuario Turismo y Sociedad 13 (2012) 171-184.

[37] Rajović G., Bulatović J., International Letters of Social and Humanistic Sciences 9 (2014) 81-99. 
[38] Nedeljković Z., The importance of agricultural cooperatives in the world, Available from: http://www.psss.rs (01.07.2014).

[39] Institute for the Study of the village, about us, Available from: http://www.proucavanjesela.rs (01.07.2014).

[40] Radovanović V., Zbornik Matice srpske za drustvene nauke 132 (2010) 41-51.

[41] Čavrak V., Zbornik Ekonomskog fakulteta u Zagrebu 1(1) (2003) 61-77. 